\title{
PERKEMBANGAN PERMUKIMAN DIPERKOTAAN \\ Studi tentang Dampak Perkembangan Permukiman Terhadap Kehidupan Sosial Keagamaan di Kota Palopo
}

\author{
Oleh: Badruzzaman
}

\begin{abstract}
This Writing is a conclucion of research, that was conducted in Palopo. This study aims to describe the model of settlement and its implication to social relationship. Data was collected using interview, observation, and documentation. Data was analized using qualitative method.

This study indicates that model of social settlement at Palopo is segregated pluralism, based on social stratification, etnic, and occupation. This implicates to social problem, such as social distance, social distortion, drugs, and prostitution.
\end{abstract}

Keywords: settlement model, social implications.

\section{A. Pendahuluan}

$\mathrm{P}$ enelitian ini bertujuan untuk mengetahui pola perkembangan permukiman di Kota Palopo dan dampaknya terhadap kehidupan sosial keagamaan masyarakat. Penelitian ini didasari oleh bahwa perubahan dan pertumbuhan kota-kota di Indonesia telah menampilkan gambaran mobilisasi sosial yang unik dan tersendiri. Perpindahan penduduk ke kota (urbanisasi) yang berasal dari berbagai kawasan budaya, etnis dan tingkat sosial yang berbeda telah mengakibatkan perubahan-perubahan dalam interaksi sosial masyarakat kota (urban) itu sendiri. Selain itu, proses urbanisasi telah pula mengakibatkan perubahan persepsi dan cakrawala hubungan masyarakat kota dengan lingkungannya, baik lingkungan alam maupun lingkungan binaan manusia.

Kemajemukan masyarakat kota, pada satu segi dapat membuka kesempatan untuk saling mengenal berbagai latar belakang perbedaan masing-masing, saling 


\section{Badruzzaman}

memotivasi satu dengan lain, saling bertukar informasi dan pengetahuan serta kearifan yang pada gilirannya menjadikan masyarakat tersebut lebih dinamis dan terbuka. Namun di segi lain, masing-masing komponen masyarakat kota yang berbeda latar belakang itu memerlukan kemampuan penyesuaian diri satu sama lain untuk dapat membina keserasian sosial dalam kebersamaan dan kehidupan bersama. Menurut Pelly (1988), konsep keserasian sosial seperti itu masih merupakan hal yang baru; pengertian dan unsur-unsurnya, faktor-faktor penentu, dan cara-cara pengukurannya masih memerlukan pengembangan dan pemikiran.

Dalam kaitan dengan perubahan-perubahan fungsi struktur masyarakat majemuk di perkotaan, hal yang dipertanyakan ialah apakah perubahanperubahan itu dapat dikondisikan sehingga dinamika masyarakat itu dapat menciptakan keserasian sosial bukan ke arah kesengajaan atau kerancuan sosial.

Pertumbuhan kota-kota di Indonesia, terutama kota-kota lama, setelah kemerdekaan menunjukkan pertumbuhan yang cepat baik penduduknya maupun permukiman dan prasarana/sarana pendukungnya. Akan tetapi gambaran wajah dari kota-kota lama masih mengesankan pola warisan kolonial dengan "wajah bermuka dua". Pusat kota merupakan wilayah permukiman elite pemerintahan dan pusat perdagangan sedang kawasan pinggiran kota yang melingkari permukiman elite pemerintahan dan pusat perdagangan adalah permukiman masyarakat biasa. Pada masa pemerintahan' penjajah kolonial Belanda, pusat kota merupakan permukiman elite pemerintahan kolonial Belanda dan pusat perdagangan yang dihuni oleh keturunan Cina, Arab, dan Timur Asing, sedang kawasan pinggiran kota dihuni oleh masyarakat bumiputera. Kedua kawasan permukiman memperlihatkan struktur dan konstruksi permukiman yang berbeda; yang satu merepresentasikan gaya hidup urban atau perkotaan, sedang yang lain gaya hidup rural atau pedesaan.

Dalam pertumbuhan kota lebih lanjut, kawasan pinggiran kota telah menyerap pendatang dan perantau yang berasal dari berbagai kawasan subbudaya nusantara, mengalir ke kota melalui saluran famili, kerabat, dan teman sekampung. Maka perkampungan pinggiran kota itu tumbuh menjadi kelompokkelompok permukiman etnis yang samakin lama semakin padat dan melebar serta semakin tinggi tingkat homogenitas identitas etnisnya.

Akibat dari perkembangan kota dan pertumbuhan permukiman demikian, pada gilirannya memunculkan pola permukiman segregatif. Pola pertumbuhan kota seperti dikemukakan di atas pada gilirannya mengakibatkan polarisasi dan 


\section{Badruzzaman}

segregasi kehidupan permukiman dalam berbagai bentuk dan jenisnya: etnis, strata sosial, okupasi dan juga agama. Segregasi permukiman demikian, pada dirinya memiliki atau membawa dampak polarisasi karakteristik budaya atau sub-budaya yang bila tidak dikelola dengan baik dapat menyimpan pontensi konflik antarpenduduk. Karena itu maka penelitian mengenai perkembangan permukiman dan dampaknya terhadap kehidupan sosial keagamaan masyarakat menjadi penting untuk diangkat sebagai topik penelitian. -

Penelitian kualitatif ini menfokuskan telaah pada pola perkembangan permukiman, segregasi permukiman, strata sosial, etnik, okupasi dan hubungan sosial. Teknik pengumpulan data yang dilakukan, yaitu: wawancara mendalam, observasi, studi dokumentasi dan studi kepustakaan. Sedangkan sumber data dan informasi ialah pemerintah daerah setempat, pejabat formal terkait, para pengembang, tokoh masyarakat dan beberapa orang dari masyarakat setiap kawasan permukiman yang dipilih secara purposif. Data yang diperoleh akan dianlisis secara deskriptif kualitatif dan interpertatif naratif.. Hasil analisis diberikan intepretasi yang relevan dengan tujuan penelitian serta dikaitkan dengan temuan-temuan lain yang terkait

\section{B. Landasan Teori}

\section{Pola Perkembangan Permukiman Perkotaan}

Menurut Elisabeth (Ever, 1982) bahwa salah satu teori yang cukup mendapatkan pengikut adalah Teori Ekologi Sosial Perkotaan, dikembangkan di sekitar tahun 20-an dan terkenal dengan nama Mazhab Chicago. Para penganut Mazhab Chikago ini akhirnya mengembangkan tiga model dasar tentang perkembangan perkotaan. Burgees menyusun tesis atau "Teori Lingkaran Konsentris". Ia menyatakan bahwa wilayah-wilayah sosial dengan ciri-ciri sosial dan ekonomi kota tersusun menyerupai bentuk lingkaran bertingkat yang mengelilingi pusat. Dan variable-variabel untuk mengukur ciri secara sistematis ini dengan struktur harga tanah; semakin dekat tanah dari pusat kota semakin mahal harganya, semakin jauh dari pusat menjadi semakin murah. Oleh Hoyt mengembangkan "Model Sector" dan beberapa yang lain mengembangkan "Teori Sel Mi". (Ever, 1986)

Model Sektor merupakan pola-pola pewilayahan permukiman dengan karakteristik sosial khususnya status sosial. Variable jenis perkajaan dan kepemilikan kasta dan serupanya yang menjadi alat ukur secara sistemik membentuk permukiman berkelompok dan terpisah. Ada permukiman nelayan, 


\section{Badruzzaman}

permukiman karyawan, perumahan-perumahan elite berkembang, disamping itu terdapat pula permukiman-permkiman kumuh. Semua itu membentuk permukiman-permukiman secara komunal yang terpisah-pisah. Sedangkan Model Inti menjadikan perbedaan etnik sebagai variable ukuran. Permukiman cenderung terbentuk berdasarkan etnik komunal. Terdapat permukiman menurut etnik tertentu, di mana permukiman tersebut memiliki seperangkat karakteristik sosial budaya, antara lain sosial, ekonomi, politik, adat istiadat dan agama masing-masing.

Sedangkan Shevky dan Bell pada akhir tahun 50-an dn awal 60-an mempropagandakan dengan nama "Analisis Wilayah Sosial". (Evers, 1986:5). Analisis Shevky dan Beel serta pengikut-pengikutnya mengenai analisa wilayah sosial pada kota-kota Amerika membatasi lebih lanjut permasalahan ekologi sosial, tetapi memperluas basis data dengan memanfaatkan bahan-bahan sensus yang lebih luas (E.Shevky dan Wendell Bel; 1974). Mereka menganggap, bahwa struktur wilayah kota dapat dijelaskan dengan tiga variabel pokok, yang masing-masing terdiri atas ciri-ciri yang berlainan. Ketiga variable ini adalah status sosial, segregari etnis dan budaya kota, di mana yang terakhir ini mempakan perpaduan ciri-ciri demografi, yang merupakan ukuran dari struktur keluarga dan rumah tangga. Wilayah sosial kota dapat digambarkan dan dipilahkan dengan memadukan ketiga varibel pokok ini..

\section{Interaksi Sosial (Hubungan Sosial)}

Para sosiolog memandang betapa pentingnya pengetahuan tentang interaksi sosal. Pengetahuan tentang interaksi sosial memungkinkan seseorang untuk memperoleh pengertian mengenai segi yang dinamis dari masyarakat atau gerak masyarakat. "Bentuk umum interaksi sosial ada empat yaitu kerjasama, persaingan, akomodasi dan konflik"(Soekanto, 2002:61). Namun Gillin dan Gillin pernah mengadakan penggolongan yang lebih luas lagi. (Soekanto, 2002).

Beberapa teori tentang interaksi sosial:

1. Menurut teori interaksi simbolik: Konsep-diri merupakan kunci teori interaksi simbolik. Menurut Colly (Johnson, 1990:52), "konsep-diri itu tergantung pada lingkungan sosial kelompok primer yang bersifat intim dan hangat secara emosional". Prilaku individu mencerminkan keinginannya untuk memperoleh dukungan sosial terhadap konsep dirinya. Tambahan pula prilakunya itu juga mencerminkan definisi mereka mengenai situasi tertentu dimana mereka terlibat.(Johnson, 1990). 


\section{Badruzzaman}

2. Menurut teori pertukaran: Homans menyatakan bahwa ada tiga konsep utamayang diperlukan dalam menganalisa kelompok kecil, yaitu kegiatan, interaksi dan perasaan. Kegiatan adalah prilaku aktual yang digambarkan pada tingkat yang sangat konkrit. Interaksi adalah kegiatan apa saja yang merangsang atau dirangsang oleh kegiatan orang lain. Sedangkan perasaan adalah keadaan subyektif sebagai suatu tanda yang bersifat eksternal atau yang bersifat prilaku yang menunjukkan suatu keadaan internal. Ketiga eleman ini - kegiatan, interaksi dan perasaan - membentuk suatu keseluruhan yang terorganisir dan berhubungan secara timbal balik. Artinya kegiatan akan mempengaruhi (dan dipengaruhi oleh) pola-pola interaksi dan perasaan-perasaan; interaksi akan mempengaruhi dan dipengaruhi oleh kegiatan dan perasaan; dan perasaan akan berhubungan timbal balik dengan kegiatan dan interaksi. Kalau satu elemen berubah maka kedua yang lain akan mungkin berubah.

3. Menurut teori struktural fungsional: Menurut prespektif ini dinamika suatu hubungan sosial mencerminkan orientasi timbal balik antara dua orang atau lebih dan bukan orientasi hanya satu orang. Hal ini dapat dilihat pada konsep interaksi itu sendiri. Semua pihak yang terlibat itu kiranya akan mau menyeimbangkan kepuasan mereka. Awal dan bertahannya suatu hubungan sosial (interaksi sosial) akan tergantung pada keberhasilan mereka dalam hal ini. Cara tertentu dimana pemuasan itu dicari dalam suatu hubungan sosial akan diatur standar normatif dan orientasi nilai kebudayaan tertentu. Karena itu menurut Parsons (Johnson, 1990) prinsip dasar keseluruhan mengenai tindakan sosial atau interaksi sosial itu diarahkan kepada tujuannya dan diatur secara normatif.

4. Menurut teori konflik. Teori ini menekankan pada kenyataan sosial di tingkat struktur sosial dari pada tingkat individu, antar pribadi atau budaya. Pada tingkat antar pribadi interaksi sosial dapat dianalisis dengan mudah menurut prinsip-prinsip yang banyak dikembangkan oleh teori konflik. Dalam pangalaman sehari-hari tentu kita menghadapi bentuk interaksi seperti konflik antar pribadi pada tingkat mikro. Akan tetapi kenyataannya bahwa konflik-konflik sosial tersebut bersumber pada struktur sosial, termasuk yang terjadi secara tatap muka. Misalnya konflik yang mungkin terjadi antar buruh kelas pekerja dengan seorang mandor dalam suatu perusahaan bukanlah terutama cerminan kebencian pribadi antara mereka melainkan lebih sebagai cerminan ketidaksesuaian dari pada kepentingan-kepentingan mereka (Jonhnson, 1990). 
Badruzzaman

\section{Kerangka Pikir}

Pertumbuhan dan perubahan kota akibat urbanisai, terutama kawasan pinggiran kota telah menjadikan kawasan tersebut sebagai permukiman kelompok etnik segregatif, serta permukiman liar yang muncul sebagai prototipe slum area. Sementara itu sejalan dengan pertumbuhan okupasi modern disektor jasa, dan industri di kota-kota, tumbuh permukiman elite/mewah yang memunculkan segregasi berdasarkan etnis, strata sosial, dan okupasi. Segregasi kehidupan permukiman antar etnis, strata sosial dan okupasi tersebut cenderung menimbulkan dampak terhadap keharmonisan kehidupan sosial.

\section{Perkembangan Permukiman}

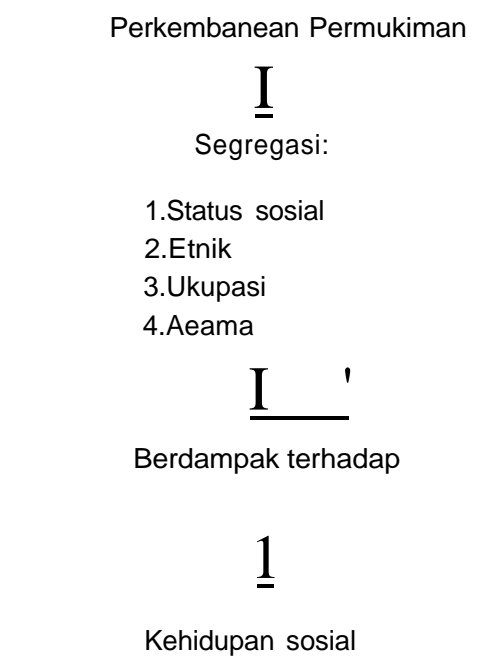

Gambar 1. Skema kerangka pikir

\section{Potret Demografis dan Geografis Kota Palopo}

Secara geografis Kota Palopo berbatasan dengan Kabupaten Luwu dan Kabupaten Tanah Toraja. Di sebelah utara Kota Palopo berbatasan dengan Kecamatan Walenrang Kabupaten Luwu, sebelah selatan berbatasan dengan Kecamatan Bua Kabupaten Luwu, sebelah barat berbatasan dengan Kecamatan Tondo Nanggala Kabupaten Tana Toraja sedangkan sebelah timur adalah Teluk Bone.

Wilayah kota Palopo memiliki luas wilayah 247,57 kilometer persegi dengan kondisi geografis terdiri atas pantai, dataran rendah dan dataran tinggi. Secara 


\section{Badruzzaman}

administratif, wilayah Kota Administratif Palopo dibagi atas 4 (empat) wilayah kecamatan, 11 desa dan 15 kelurahan, 39 dusun dan 50 lingkungan, 228 rukun warga $(\mathrm{RW})$ atau rukun keluarga $(\mathrm{RK})$, serta 526 rukun tetangga (RT).

Bila dirinci menurut penganutan agama, distribusi jumlah penduduk Kota Palopo variatif. Terdapat $83.44 \%$ jumlah penduduk yang beragama Islam. Sedangkan selebihnya adalah penganut agama Kristen Katolik, Kristen Protestan, Hindu dan Budha. Penduduk yang beragama Islam pada umumnya terdiri dari "orang etnis Bugis Ware', Bugis Luwu atau Luwu", dan para pendatang bam dari daerah Bugis seperti Wajo, Bone, Sidrap, dan lain-lain; juga para pendatang dari daerah-daerah provinsi di luar Sulawesi Selatan seperti antara lain dari Jawa dan Lombok (Nusa Tenggara Barat). Penduduk yang beragama Kristen Protestan dan Katolik pada umumnya terdiri dari orang Toraja, baik Toraja asli maupun Toraja Luwu. Penduduk yang beragama Hindu pada umumnya adalah pendatang dari daerah Bali, terbanyak transmingran, sedangkan penduduk yang beragama Budha hampir seluruhnya terdiri dari warga keturunan Cina.

Kota Palopo yang saat ini menjadi kota (setingkat kabupaten) maka dapat dipahami kalau hampir semua fasilitas perkantoran dan sarana fasilitas umum seperti kantor pemerintahan daerah itu sendiri, kantor pos, terminal, rumah sakit, sekolah, dan pusat jasa pelayanan kebutuhan dasar seperti listrik, air bersih, dan telepon yang berpusat di dalam kota. Sejalan dengan fungsi yang diembannya maka fasilitas pelayanan umum yang ada masih perlu ditingkatkan yang disesuaikan dengan potensi dan kemampuan yang dimiliki. Hanya saja alokasi-alokasi fasilitas pelayanan umum khususnya untuk pembangunan baru perlu diletakkan dalam kerangka Rencana Umum Tata Ruang Kota yang dikaitkan dengan pengembangan subpusat pertumbuhan pada bagian wilayah kota yang potensial.

Masyarakat Luwu, sejak masa kerajaan sudah terbiasa hidup dan bergaul dalam suasana hetrogenitas multietnis tanpa benturan-benturan yang berarti. Karena itu kelompok dari Jawa yang didatangkan Pemerintah Hindia Belanda pada tahun 1930-an yang kemudian disusul dengan kedatangan para transmigran asal Jawa, Bali, Lombok, dan Sunda sejak tahun 1970-an mereka tidak menemukan hambatan dalam rangka harmonisasi hubungan dan integrasi sosial, baik yang berlatar belakang perbedaan etnis maupun perbedaan agama.

Masyarakat Luwu merasa bangga mewarisi nilai-nilai budaya luhur yang mereka percaya diletakkan dasarnya oleh raja Luwu pertama priode La Galigo bernama Batara Guru dan anaknya bernama Batara Lattu'. Nilai budaya luhur 
yang dimaksud bertupa tiga prinsip hidup dan kekuatan moral yang diperlakukan secara tegas (Bugis: getteng), yaitu: adele' (keadilan), lempu' (kejujuran), dan tongeng (kebenaran). Ketiga nilai budaya luhur dijadikan dasar ukuran seseorang atau masyarakat Luwu dalam sikap dan perilaku. Penerapannya diutarakan secara "bertangga turun" atau berdasarkan prinsip keteladanan; "yang di atas" memberikan teladan kepada "yang di bawah" dalam hal penerapannya.

Kota Palopo yang cikal bakalnya mulai dibangun pada awal abad ke-17 Masehi (1610) oleh Raja La Baso Langi MatinroE ri Gowa, secara fisik mengalami perubahan besar pada masa pemerintahan Hindia Belanda kemudian mengalami perubahan yang lebih besar lagi dalam masa lima dekade pasca kemerdekaan R.I.

Pusat kota yang semula berintikan istana datu/raja dan dikelilingi oleh rumah para pejabat dan aparat kerajaan serta para kaum kerabatnya, ketika masa pemerintahan Hindia Belanda diperluas dengan membangun permukiman elit pemerintahan kolonial (perkantoran dan rumah kediaman) dilengkapi dengan sarana/lapangan olah raga dan gereja. Masjid yang hanya satu-satunya ketika itu yakni Masjid Tua (yang dibangun pada awal masuknya Islam di Luwu kirakira tahun 1604), tetap difungsikan. Sedangkan di sebelah utara istana raja dibangun pusat perdagangan yang ketika itu dimukimi oleh orang Cina dan orang Timur Asing lainnya seperti orang Arab dan India/Pakistan. Penduduk asli ditempatkan melingkari permukiman elit (sebagian besar berada di sebelah timur istana datu). Antara kedua kawasan permukiman tersebut terdapat perbedaan jelas mengenai struktur dan konstruksi permukiman serta perbedaan kultur permukiman. Perbedaan struktur dan konstruksi permukiman tampak pada segi konstruksi bangunan, teknologi, dan susunan tata ruang. Sedangkan perbedaan budaya tampak jelas dalam gaya hidup (way of life), yang satu merepresentasikan gaya hidup urban atau perkotaan, sedang yang lain merepresentasikan gaya hidup pedesaan yang bersifat tradisional (Sarita, 2000).

Pertumbuhan kota Palopo selama 5 (lima) dekade pasca kemerdekaan mengalami perubahan besar. Permukiman elit di pusat kota telah berganti penghuninya, dari birokrat kolonial ke birokrat nasional, sedang kawasan perdagangan juga sebagian telah berganti penghuni; orang Arab dan India secara berangsur menghilang dan digantikan oleh orang pribumi sementara orang Cina sebagian masih tetap bertahan. Wajah fisik kawasan perdagangan lama di pusat kota tidak banyak mengalami perubahan, walaupun pasar telah dipindahkan ke arah selatan sekitar 2 kilometer dari pasar lama. 


\section{Badruzzaman}

\section{Pola perkembangan Permukiman dan Dampaknya terhadap Kehidupan Sosial Keagamaan Masyarakat}

Perkembangan permukiman di perkotaan tampak masih mengikuti pola kolonial. Menurut Ever (Ever, 1986) bahwa mungkin penting dicatat bahwa semua kota-kota besar di Asia Tenggara berasal dari zaman kolonial. Kota-kota kolonial ini telah tumbuh berdasarkan asumsi bahwa suku dan asal etnik merupakan prinsip-prinsip utama dari organisasi sosial. Lebih lanjut dikatakan bahwa pada awal perkembangan Kota Betavia (Jakarta) pada abad 17 dan 18 ibu Negara Hindia Belanda, mempunyai kampung-kampung terpisah untuk orang Balanda, Ambon, Makassar, Sumbawa, Bugis, Bali, Jawa, Sunda, Madura, Bima dan lain sebagainya.

Gambaran yang serupa tampak mulai berkembang di Kota Palopo. Pola perkembangan permukiman di Kota Palopo memiliki kecenderungan ke ara serupa dengan apa yang diungkapkan oleh Ever, yaitu pola perkembangan permukiman yang berrpola segregasi etnik.

Sesuai dengan penjelasan terdahulu bahwa yang dimaksud dengan segregasi etnik adalah pengelompokan masyarakat berdasarkan kesadarannya terhadap identitas suatu kebudayaan tertentu. Misalnya kesadarannya sebagai seorang yang beridentitas suku Bugis, Toraja, Makassar, Mandar, Jawa, NTT, keturunan Cina dan lain sebagainya.

Dari hasil penelitian di Kota Palopo, ada dua lokasi penelitian yang menampakkan kategori perkembangan perkotaan menurut segregasi etnik. Yang pertama adalah perkembangan permukiman ke arah pantai dan permukiman yang berkembang mengikuti jalur jalan ke Tana Toraja.

Permikiman yang disebut pertama merupakan permukiman mayoritas dihuni oleh para nelayan. Memang bahwa permukiman pada jalur pantai monoetnik yakni suku Bugis, akan tetapi kesegregasian terletak pada kategori etnik Bugis Luwu dan etnis Bugis pendatang baru. Pertama, etnik penduduk asli (Bugis Luwu) dan yang lainnya adalah etnis asal daerah-daerah Bugis yang berdekatan dengan Luwu, seperti Sidrap, Bone, Wajo dan lain-lain.

Sebagai terungkap terdahulu bahwa suku Bugis asli Luwu mayoritas memilih mendirikan rumah-rumah di sepanjang pantai. Keadaan permukiman nelayan tersebut tampak kumuh dan tidak beraturan. Pemilihan lokasi tersebut dikarenakan untuk lebih menunjang pekerjaan mereka mencari ikan laut lepas. Tampak memilik komunitas tersendiri dan berkelompok. Sedangkan suku Bugis 


\section{Badruzzaman}

pendatang, lebih memilih mengembangkan permukiman yang agak jauh masuk ke daratan. Di lokasi tersebut mereka lebih menggeluti pekerjaan yang bersifat domistik yaitu memelihara ikan/rumput laut secara tambak.

Permukiman kedua yang berkategori segregasi etnik adalah permukiman yang berkembang mengikuti jalur jalan ke Tana Toraja. Sebagaimanaterungkap terdahulu pada uraian terdahulu bahwa permukiman sepanjang jalur jalan dari Kota Palopo ke arah Tana Toraja banyak dihuni oleh penduduk pindahan dari Kabupaten Tana Toraja. Mereka datang secara berangsur ke daerah tersebut dan membentuk suatu permukiman. Pada mulanya ada beberapa keluarga yang mendapat tempat bermukim dengan jalan membeli dari pemilik tanah penduduk asli setempat. Kemudian secara berangsur mereka yang telah membuat permukiman baru di tempat itu, karena mengajak keluarga/famili atau teman seasalnya untuk pindah mendirikan rumah di tempat berdekatan yang memang masih kosong dan akan dijual oleh empunya. Akhirnya lokasi sepanjang jalan menuju Tana Toraja itu menjadi sebuah permukiman yang relatif padat yang sebagian besar penghuninya adalah orang Toraja.

Selain itu, Ever juga menjelaskan bahwa pola perkembangan perkotaan .yang lain ialah berpola - sesuai dengan tesis Burgees - "Lingkaran Konsetris ". Ia menyatakan bahwa wilayah-wilayah sosial dengan ciri sosial dan ekonomi kota tersusun menyerupai bentuk "lingkaran bertingkat" yang mengelilingi pusat.

Pola perkembangan permukiman lingkaran konsentris ini masih tampak di Kota Palopo. Permukiman yang berkategori status sosial berada pada pusat kota. Sebagaimana diuraikan terdahulu bahwa di permukiman pust kota terjadi perkembangan permukiman yang cukup tinggi. Gedung-gedung baru yang bermunculan seperti hotel, rumah-rumah elit (menurut ukuran setempat) dan gedung perkantoran, di samping perumahan penduduk yang sebagian masih berbentuik rumah panggung. Selain itu terdapat pula kompleks perumahan (asrama) TNI dan POLRI. Di permukiman pusat kota tersebut, tidak jelas adanya segregasi permukiman secara berkelompok dan tidak terlihat adanya rumahrumah kumuh. Namun demikian, pusat Kota Palopo ini didominasi oleh pemukimpemukim yang berstatus sosial tinggi.

Pola perkembangan permukiman selanjutnya yang berkembang adalah pola perkembangan permukiman yang berkategori segregasi okupasi. Pola yang terakhir ini berada di daerah pantai. Yang dimaksud dengan segregasi okupasi adalah

pengelompokan masyarakat berdasarkan jenis pekerjaannya. Pengelompokan tersebut dapat berupa petani, nalayan, karyawan, wiraswasta dan buruh. 


\section{Badruzzaman}

Permukiman daerah pantai dimukimi oleh pada nelayan. Para nelayan Bugis asli Luwu yang mencari ikan di laut lepas mayoritas bermukim di pesisir pantai. Sedangkan warga Bugis pendatang yang mata pencahariannya memelihara ikan/ rumput laut melalui bertambak membangun permukiman yang terpisah. Mereka lebih memilih mengembangkan permukiman yang agak jauh masuk ke darah daratan.

Dalam upaya menanggulangi pola perkembangan permukiman yang cenderung segregatif tersebut, pemerintah setempat telah berupaya mengembangkan program perumahan nasional. Permukiman Perumnas yang tumbuh menjamur di Kota Palopo di satu segi memberikan kontribusi yang berarti dalam upaya membantu masyarakat penduduk Kota Palopo mengatasi masalah keterbatasan perumahan. Namun demikian pembangunan Perumnas yang belum didasarkan pada suatu program Rencana Umum Tata Ruang Kota, menimbulkan beberapa implikasi dalam kaitan dengan keharmonisan kehidupan di permukiman di Kota Palopo.

Beberapa permasalahan yang muncul kemudian dari program ini. Program ini tampaknya lebih berperan pada peningkatan mutu perumahan masyarakat dengan menyediakan jenis rumah yang layak huni dan sehat dan diperuntukkan bagi masyarakat yang kurang mampu. Namun dampak yang lain berupa mengurangi kesegregasian kehidupan perkotaan belum teratasi, bahkan lebih menanbah kompleksitas permukiman di Kota Palopo. Warga yang bermukim di Perumnas pada umumnya adalan PNS dan karyanwan swasta. Sedangkan yang bermukim di daerah-daerah antara, — dalam hal ini daerah perbatasan antara dua atau tiga Perumnas - mayoritas didiami oleh para pelaku sektor informal, seperti tukang becak, penjual sayur dan lain sebagainya. Selain itu Perumnas, cenderung menunjukkan segregasi permukiman berdasarkan kelas sosial menengah ke bawah.

Hal yang sama pun tampak mulai terjadi di Kota Palopo, kempleksitas keberadaan permukiman yang segregatif berdampak pada kehidupan sosial masyarakat. Setidaknya dampak-dampak tersebut dapat dibagi kepada dampak fisik dan dampak sosial. Dampak fisik dari kondisi perumahan yang segregatif khususnya pada lokasi-lokasi yang dijadikan sampel dalam penelitan ini, lebih berkaitan dengan permasalahan dampak lingkungan. Sedangkan dampak sosial dari perkembangan permukiman tesebut lebih berkaitan dengan prilaku masyarakat dan kriminalitas.

Beberapa yang berkaitan dengan dampak fisik dari pola perkembangan permukiman yang segregatif di Kota Palopo setelah diidentifikasi, antara lain berupa: 


\section{Badruzzaman}

1. Munculnya daerah-daerah herder line (daerah-darah antara). Daerah-daerah border line ini berkembang di daerah-daerah perbatasan antara dua atau lebih perumahan nasional yang sekarang ini tampak menjamur di Kota Palopo.

2. Kesemrawutan permukiman. Keadaan ini lebih berkembang di daerah pantai yang mana mayoritas yang bermukim di daerah tersebut adalah para nelayan. Demikian halnya yang terjadi pada permukiman jalur ke Tana Toraja. Rumah-rumah yang didirkan oleh masyarakat migran dari Kabupaten tana Toraja tersebut tidak tertata dengan baik.

3. Pencemaran lingkungan. Kebersihan lingkungan permukiman kurang terindahkan. Permukiman memiliki beban lingkungan yang tinggi sehingga menimbulkan pencemaran seperti pembuangan sampah dan genangan air di selokan. Keadaan ini ditemui di semua lokasi penelitian yang dijadikan sample yaitu daerah Perumnas, pantai, jalur jalan ke Tana Toraja dan pusat kota khsususnya pada pusat-pusat perbelanjaan.

Sedangkan beberapa dampak sosial yang diakibatkan oleh perkembangan permukiman yang segregatif tersebut, antara lain ialah :

1. Kesenj angan sosial. Kesenj angan sosial, akibat perkembangan permukiman, terjadi di ke empat lokasi yang dijadikan sampel. Di daerah Perumnas, kesenjangan sosial terjadi antara warga yang bermukim di Perumnas yang mayoritas PNS dan karyawan dengan' warga yang bermukim di daerah border line yang mayoritas tukang becak dan para penjual sayur. Hal yang sama terjadi di daerah permukiman jalur ke Tana Toraja. Kesenjangan sosial antara para penduduk migran dari Tana Toraja dengan penduduk asli Kota Palopo. Sedangkan di daerah pantai, kesenjangan sosial antara para nelayan Bugis pendatang dan Bugis asli Palopo.

2. Ketegangan sosial. Ketegangan hubungan sosial dapat ditemui di daerah permukiman nelayan dan daerah pemukiman jalur ke Tana Toraja. Bahkan ketegangan antar umat beragama ditemui di daerah yang disebut terakhir.

3. Kerawanan sosial. Kerawanan sosial yang berupa pencurian, penjabretan dan lain-lain seringterjadi di daerah Perumnas dan permukiman nelayan di pantai.

4. Dampak sosial lainnya, antara lain miras, judi narkoba dan portitusi.

Sebagaimana terungkap terdahulu bahwa Kota Palopo merupakan kota yang multi etnik. Keadaan tersebut berlangsung sejak awal-awal kemerdekaan. KebupatenLuwu sebagai bagian dari Negara Kesatuan Republik Indonesia tentu 
saja membuka diri untuk menerima setiap warga negara yang berasal dari daerah-daerah lain dengan latarbelakang etnis dan budaya masing-masing. Bahkan sebelum kemerdekaan, yakni ketika masa pemeritahan Hindia Belanda, daerah Luwu telah memerima pindahan penduduk secara besar-besaran dari pulau Jawa sekitar tahun 1930-an melalui program kolonisasi. Setelah kemerdekaan RI, pemindahan penduduk dari pulau Jawa keluar Jawa dilanjutkan melalui program transmigrasi. Sejak tahun 1970, daerah Luwu (kabupaten Luwu dan Kabupaeten Luwu Utara) selalu dijadikan sasaran program transmigrasi. Daerah Luwu telah menampung penduduk yang dipindahkan dari daerah-daerah lain dengan latar belakang etnis: Jawa, Sunda, Bali, Lombok (NTB) dan Flores (NTT). Selain itu kota Palopo juga banyak didatangi oleh warga daerah berdekatan, seperti dari daerah Tana Toraja (etnis Toraja) dan daerah-daerah Wajo, Soppeng, Bone, Sidrap (etnis Bugis) serta dari daerah Jeneponto, Takalar, Makssar dan sekirtarnya. (Badrun, 2002).

Kondisi multietnik tersebut di atas turut mendukung kecendrungan segregasi etni di Kota Palopo. Pola permukiman di perkotaan yang cenderung terdefrensiasi menurut karakteristik tertentu, tampak sangat didukung oleh keadaan sosial kultur masyarakat yang berkembang di Kota Palopo.

Dalam upaya menanggulangi dampak perkembangan permukiman yang segregatif, khususnya segergasi etnik, upaya asimilasi perlu dilakukan. Menurut Soekanto (2002) bahwa "asimilasi merupakan proses sosial dalam taraf lanjut". Ia ditandai dengan adanya usaha-usaha mengurangi perbedaan-perbedaan yang terdapat antara orang-perorangan atau kelompok-kelompok manusia dan juga meliputi usaha-usaha untuk mempertinggi kesatuan tindak, sikap dan proses-proses mental dengan memperhatikan kepentingan-kepentingan dan tujuan-tujuan bersama.

Karena itu upaya asimilasi merupakan hal yang mendesak perlu dilakukan dalam menanggulangi kondisi perkembangan permukiman yang segregatif etnik di Kota Palopo. Upaya untuk lebih meningkatkan integritas masyarakat, perlu lebih dipertimbangkan. Sikap-sikap toleransi tehadap kelompok-kelompok manusia yang berbeda kebudyaannya dengan kebudayaan sendiri perlu dikembangkan. Kondisi multietnik di Kota Palopo tentunyatersimpan makna bahwa multibudaya pun terjadi. Setiap etnik memiliki kebudayaan yang berbeda dan bahkan bertentangan dengan kebudayaan etnik yang lain. Kondisi ini di satu sisi sangat potensial menciptakan konflik antar etnik tetapi di sisi lain pun potensial untuk dikembangkan ke arah "kesatuan dalam keragaman". Karena itu sikap toleransi antara kelompok etnik yang saling berbeda kebudayaannya sangat perlu dikembangkan agar integritas dan hubungan sosial dapat berlangsung secara teratur, damai, tentram dan aman. 


\section{Badruzzaman}

Selain itu, sikap saling menghargai kebudayaan yang berbeda perlu dikembangkan. Setiap kebudayaan memiliki kelebihan-kelebihan dan kekurangankekurangan bila dipandang dari pendukung kebudayaan yang berbeda. Enik tertentu mungkin memandang suatu kebudayaan etnik lain memiliki nilai-nilai yang dianggap tidak bagus, demikian sebaliknya. Demikianlah yang terjadi antara sistem kebudayaan etnik Toraja dan etnik Bugis Kelurahan Boting. Antara kedua etnik tersebut mempunyai perbedaan kebiasaan yang sangat kontradiktif seperti memelihara hewan tertentu (babi). Oleh karena itu, sikap saling menghargai kebudayaan yang didukung oleh etnik lain - masing-masing mengakui kelemahan dan kekurangan sistem kebudayaan - akan mendekatkan kedua komunitas yang berbeda yang menjadi pendukung kebudayaan tersebut. Sebab apabila ada prasangka, maka hal demikian akan menjadi penghabat proses asimilasi.

Ada suatu hal yang agaknya dapat mempelancar proses asimilasi. Mennurut Soekanto (2002), hal tersebut adalah amalgamation atau perkawinan campuran. Lebih lanjut dikatakan bahwa perkawinan campuran terjadi apabila seorang warga dari golongan enik tertentu menikah dengan warga golongan etnik yang lain, apakah itu antara golongan etnik minoritas dengan mayoritas atau sebaliknya. Proses asimilasi dipermudah dengan adanya perkawinan campuran, walaupun memakan waktu agak lama.

Selain kondisi etnik yang mendukung perkembangan permukiman yang segregatif di Kota Palopo, kondisi pemeluk agama pun turut. Sebagai terungkap terdahulu bahwa masyarakat Kota Palopo menganut multi agama. Lima agama besar yang berkembang di dunia seperti Islam, Kristen Katolik, Kristen Protestan, Budha dan Hindu masing-masing memiliki penganut. Perbandingan persentase yang telah diungkap terdahulu memperlihatkan keadaan yang cukup signifikan dalam kesegregasian.

Salah satu ciri khas masyarakat bangsa Indonesia ialah pluralitas di berbagai hal, termasuk agama. Kemajemukan agama memiliki potensi yang sangat sensitif untuk dapat menciptakan konflik antar umat beragama manakala terjadi benturan kepentingan antara suatu umat beragama dengan umat beragama yang lain.

Konflik yang melibatkan antar penganut agama, memang belum pernah terjadi di Kota Palopo, akan tetapi kemungkinan-kemungkinan munculnya potensi itu sangat berpeluang. Hal ini didukung oleh kondisi ketegangan antara penganut agama yang tampak terjadi di daerah-daerah tertentu, khususnya di Kelurahan Boting. Keadaan permukiman yang berpola komunitas menurut agama (berkelompok menurut jenis agama) sangat mendukung terjadinya konflik antar 


\section{Badruzzaman}

kelompok. Kondisi berkelompok masyarakt menurut agama tersebut potensial mendukung munculnya konflik komunal seperti yang terjadi di Ambon, dan Sampit. Keadaan tersebut di atas, tampaknya tinggal menuggu insiden pemicu konflik.

Karena itu, dalam upaya menghidari dan menanggulangi munculnya konflik antar penganut agama Mushawir (Badan Litbang dan Diklat Keagamaan, 2003) menyatakan perlunya untuk menemukan akar-akar permasalahan yang memicu munculnya konflik agama itu. Konflik-konflik sosial dan tindakan kekerasan yang terjadi dalam masyarakat disebabkan oleh banyak faktor. Faktor utama yang mendorong terjadinya konflik adalah kurangnya political wiil dari pemerintah dalam menegakkan keadilan sosial maupun meningkatkan kesejahteraan seluruh rakyat Indonesia. Selain itu lemahnya sistem pendidikan dan pengajaran nasional, juga menjadi akar permasalahan.

Dalam kaitan dengan pengembangan permukiman, penataan permukiman Kota Palopo hendaknya bernuansa fluralistik. Penataan permukiman bernuansa fluralistk tidak hanya pada lingkungan desa atau kelurahan dan lingkungan seperti yang telah dikembangkan saat ini. Namun lebih kepada pengembangan permukiman yang bernuansa fluralistik pada lingkup ketetanggaan. Ada suatu kondisi dimana keragaman ciri khas masyarakat berbaur dalam wilayah ketetanggaan. Penganut agama tertentu bertetangga dengan penganut agama yang lain. Demikian halnya dengan masyarakat yang beretnik tertentu hidup bertetangga dengan masyarakat etnik yang lain.

Perkembangan yang real saat ini pada setiap urbanisasi (perkembangan perkotaan) adalah polarisasi permukiman cenderung menurut strata sosial. Di suatu wilayah permukiman perkotaan berkembang permukiman elite yang ditandai dengan gedung-gedung yang tinggi dan indah, keamanan dan kenyamanan hidup terjaga serta kebersihan lingkungan terindahkan. Situasi permukiman yang tampak mengisolir diri dengan bangunan pagar beton yang tinggi sebagai pemisah antara komunitas mereka dengan masyarakat yang lain. Karena itu bermunculan pula kompleks-kompleks perumahan elite, misalnya Kompleks Perumahan Bank tertentu, Kompleks Perumahan Perwira, Kompleks Perumahan Gubernur, Kompleks Perumahan Dosen dan lain-lain. Bahkan polarisasi tersebut bernuansa etnik, seperti berkembang permukiman-permukiman menurut etnik tertentu, seperti pecinan (Kota Cina). Pada wilayah yang lain tampak pula berkembang pemukiman yang berstrata sosial rendah. Di beberapa wilayah perkotaan tampak pula berkembang permukiman-permukiman kumuh, penuh dengan ketidakamanan, sampah berserakan, dan lain sebagainya. Keadaan permukiman iiii sangat tampak di daerah-daerah pinggiran kota. 


\section{Badruzzaman}

Kondisi yang demikian ini pula berkembang di Kota Palopo. Berbagai bangunan tinggi dan indah mulai berkembang di pusat Kota Palopo, baik fasilitasfasilitas umum, ekonomi, pendidikan dan budaya. Lokasi permukiman di pusat kota, diselingi oleh bangunan fasilitas umum, seperti fasilitas pendidikan (sekolahsekolah dari tingkat TK, SD, SLTP, SLTA, dan PT), fasilitas kesehatan (Rumah Sakit dan Puskesmas), fasilitas peribadatan (rumah-rumah ibadah : masjid, masallah, gereja), fasilitas perkantoran umum: Kantor Walikota, Kantor Polisi, Kantor TNI, Kantor Pos, Kantor Telepon, Kantor PDAM, Kantor PAM, Kantor PLN) dan fasilitas olah raga serta hiburan/kesenian. Sedangkan di daerah-daerah pinggiran kota masih tampak kumuh dan sarat dengan beban lingkungan.

Keadaan ini memperlihatkan adanya kesenjangan sosial. Ada situasi dimana terdapat berbedaan kondisi sosial ekonomi masyarakat di Kota Palopo. Pusat Kota Palopo memparlihatkan keadaan sosial ekonomi masyarakat yang tinggi, ditandai dengan bangunan rumah serba permanen dan indah serta fasilitas kehidupan sosial yang lengkap. Sedangkan di daerah pinggiran kota memperlihatkan kondisi sosial ekonomi yang rendah dengan wajah kumuh, sarat dengan beban lingkungan dan kerawanan sosial.

Keadaan tersebut perlu dicarikan solusi segera. Upaya untuk membenahi penataan permukiman yang berkaraskteristik status sosial tersebut dengan memperhatikan stuktur sosial dan ekologi permukiman perlu dikembangkan. Penataan permukiman yang meminimalisir kesan berpola segregasi menurut strata sosial segera dilakukan. Hal ini disebabkan oleh karena penundaan lebih lama terhadap upaya tersebut akan lebih menambah kompleksitas permasalahan sosial yang diakibatkan oleh kondisi permukiman di Kota Palopo. Sebagai contoh ialah kemungkinan dampak-dampak sosial yang lain mungkin dapat muncul, seperti kemungkinan munculnya konflik yang dipicu oleh kepentingan parsial seperti ekonomi, sosial, bahkan politik tertentu.

Dalam menanggulangi dampak tersebut di atas, pemerintah Kota Palopo melakukan beberapa upaya. Terdapat beberapa kegiatan yang diprogramkan pemerintah dalam upaya menangani berbagai keadaan fisik permukiman dan dampaknya. Upaya penanganan masalah-masalah pembangunan fisik kota diprogramkan dalam bentuk Rencana Umum Tata Ruang Kota (RUTRK) dalam konteks Kota Palopo sebagai ibukota Kabupaten Luwu dan sebagai Kota Ad-ministratif, dalam program berjangka 10 tahun (1993/1994-2003/2004). Sebagai landasan operasional dari realisasi RUTRK tersebut, pada tahun 1993 dikeluarkan Surat Keputusan Bupati Kepala Daerah Kabupaten Luwu tentang tata ruang kota. Akan tetapi proses perkembangan kota kemudian tampaknya 
tidak sesuai dengan RUTRK yang pelaksanaannya didukung oleh surat keputusan bupati. Pertumbuhan bangunan dalam kota lebih mengikuti pola perizinan 1MB (Izin Mendirikan Bangunan) yang telah ditentukan sebelumnya, daripada mengikuti ketentuan-ketentuan yang termaktub dalam surat keputusan bupati tersebut. Menjelang akhir masa orde baru berbagai krisis menimpah negeri kita, baik krisis ekonomi, krisis moneter, krisis pemerintahan, dan krisis integrasi. Situasi nasional tersebut betapapun mempengaruhi kehidupan masyarakat kota Palopo pada umumnya, termasuk pelaksanaan kebijakan dan program pembangunan kota Palopo sesuai RUTRK yang telah disusun sebelumnya.

Adapun upaya penanganan masalah-masalah sosial, terutama yang bermunculan sejak era reformasi, selain dilakukan secara fungsional oleh pihakpihak terkait, juga dilakukan upaya penanganan secara bersama-sama atau terpadu melaui wadah atau lembaga kerjasama yang khusus dibentuk untuk keperluan penanganan masalah-masalah sosial tersebut, seperti antara lain: Forum Komunikasi Antar Ummat Beragama (FKAUB).

Salah satu masalah yang cukup potensial mengandung konflik bila tidak segera dicarikan solusinya ialah masalah pemeliharaan hewan ternak babi oleh masyarakat penduduk asal Tana Toraja yang bermukim di Kelurahan Boting dan Patte'ne di pinggir jalur jalan menuju Tana Toraja. Penduduk asal Tana Toraja tersebut memiliki kebiasaan memelihara ternak babi di pekarangan rumah mereka masing-masing, dan kebiasaan tersebut diberlakukan'pula di tempat permukiman baru. Kebiasaan mereka tersebut menurut mereka, di samping memiliki nilai solidaritas kekeluargaan yang mereka masih junjung tinggi juga memiliki nilai ekonomi. Akan tetapi penduduk asli yang berdekatan rumah atau permukiman merasa terganggu dengan kebiasaan memelihara babi tersebut. Mereka mengeluhkan cara pemeliharaan ternak tersebut yang tidak mengindahkan kebersihan dan keserasian lingkungan. Kotoran ternak babi tersebut menimbulkan bau yang dianggap "sangat mengganggu" rasa penciuman penduduk asli setempat, sementara kebersihan lokasi kadang ternak kurang diperhatikan sehingga mengganggu dan mencemari lingkungan petmukiman. Selain itu, limbah dan air pencucian limbah kotoran hewan ternak babi dialirkan ke sungai yang sepanjang perjalanan menuju pusat kota, air sungai tersebut digunakan penduduk asli yang beragama Islam untuk kebutuhan mandi, mencuci, dan mengambil air wudhu.

Persoalan tersebut sudah beberapa kali dibicarakan di dalam wadah FKUAB dan setiap kali dibicarakan selalu ada solusi sementara, namun hingga penelitian ini dilaksanakan (Maret 2002) masalahnya belum tuntas. Bahkan persoalan 


\section{Badruzzaman}

tersebut telah dibicarakan di DPRD Kabupaten Luwu dalam upaya menemukan solusi yang memiliki dasar kuat, antar lain dengan melalui Perda (Peraturan Daerah ) Kabupaten Luwu, namun hingga Maret 2002 belum juga nampak realisasinya. Para tokoh agama yang anggota-anggotanya "terlibat" dalam kasus tersebut semuanya berharap bahwa masalah tersebut akan ditemukan solusinya lewat Perda yang kini sementara dibicarakan di DPRD setempat.

Selain itu dibentuk pula tim pengendali narkoba. Beberapa upaya penanganan secara persial telah dilakukan antara lain: pembentukam Tim Pengendalian Narkoba; pembentukan Tim Penanggulangan Stabilitas Keamanan; pembentukan Tim/Koordinator Penanggulangan Kemaksiatan. Namun demikian tindak lanjut dari upaya-upaya tersebut, kurang nampak. Yang disebabkan antara lain karena adanya keterbatasan kewenangan. Sementara itu, tuntutan kebutuhan penanganan dini dan cepat terhadap masalah-masalah patologi sosial semakin mendesak. Maka dibentuk sebuah badan untuk menangani masalah penyakit sosial dengan nama Badan Koordinasi Operasi Pengendalian dan Penaggulangan Patologi Sosial.

Berkaitan dengan tugas pokok tersebut maka fungsi badan antara lain:

1. Menanamkan pemahaman, meningkatkan kesadaran, dan penghayatan terhadap dampak penyakit sosial.

2. Memelihara dan memupuk tanggung jawab sosial, semangat kebersamaan dalam memberantas penyakit sosial.

3. Melaksanakan usaha-usaha pencegahan, penanggulangan dan rehabilitasi terhadap penyakit sosial.

\section{E. Penutup}

Berdasarkan uraian terdahulu maka hasil penelitian ini dapat disimpulkan, sebagai berikut:

1. Perkembangan permukiman di Kota Palopo, secara umum, masih cenderung berpola sentries dengan pengelompokan berdasarkan strata sosial. Disamping itu perkembangan kota dan permukiman di Kota Palopo selama lima dasawarsa pasca kemerdekaan yang cenderung mengikuti keinginan masyarakat dan tuntutan urbanisasi, sementara belum ada suatu perencanaan umun Tata Ruang Kota yang baku untuk dijadikan acuan, pada gilirannya memunculkan segregasi permukiman yang cenderung berpola: segregasi etnik, okupasi dan status sosial. 
2. Dampak yang muncul dari perkembangan permukiman tersebut, selama ini pada umumnya masih dapat diatasi secara fungsidnal oleh pihak-pihak terkait. Namun beberapa hal yang tampak jelas dari dampak pola perkembangan permukiman di Kota Palopo adalah antara lain berkaitan dengan dampak fisik dan dampak sosial. Dampak fisik berupa berkembangnya daerah-daerah border line, kesemrawutan permukiman dan pencemaran lingkungan. Sedangkan yang berkaitan dengan dampak sosial antara lain munculnya kesenjangan sosial, kerawanan sosial, ketegangan sosial dan hal-hal yang berkaitan degan miras, narkoba, portitusi dan pencurian.

Berdasarkan hal tersebut di atas, peneliti menyarankan beberapa hal

1. Analisis evaluasi terhadap strategi penanganan perkembangan dan pembangunan Kota Palopo perlu dilakukan. Bahwa kelemahan-kelemahan yang ada baik yang bersifat fisik, alamiah dan buatan maupun sosial, demikian pula hal-hal yang diprediksikan sebagai ancaman pada dasarnya merupakan tantangan yang harus mendatangkan peluang penanganan yang sungguhsungguh dengan skala prioritras. Segala sumber daya yang dimiliki, baik yang masih berbentuk potensi maupun yang telah diwujudkonkritkan dalam bentuk Five's M(man, material, machine, money and method) hendaknya didayagunakan sebaik mungkin (secara efektif dan efisien).

2. Straregi penanganan yang dituangkan dalam planologi dengan lebih memperhatikan struktur sosial dan ekologi permukiman dapat mendorong pengembangan keharmonisan hubungan sosial dan integritas bangsa. Teknik penanganan disusun dalam suatu program yang terarah, sistematis, bertahap, berkesinambungan serta tidak muluk-muluk. Keterpaduan juga merupakan salah satu unsur strategi penting yang perlu diindahkan dalam penanganan perkembangan dan pembangunan kota.

3. Selain itu, upaya mengantisipasi dampak dari perkembangan permukiman yang segregatif, dapat dilakukan dengan, pemda setempat, membentuk lembaga sosial yang dapat mengikat persaudaraan masyarakat. Seperti misalnya lembaga kerukunan keagamaan atau kerukunan kebangsaan (anggotanya berasal dari berbagai etnik dan agama yang ada di Kota Palopo). Dapat pula berupa permbuatan sarana sosial - diantara permukiman yang segregatif - yang dapat mempertemukan setiap hari masyarakat yang berbeda etnik, agama dan status sosial, seperti pembangunan lembaga pendidikan, pusat perkonomian atau semacam gedung pertemuan. 


\section{DAFTAR PUSTAKA}

Badan Pusat Statistik Kabupaten Luwu/Polopo, 2002, Kota Palopo dalam Angka 2002, Palopo: Kerjasama Pemkot Palopo dengan BPS Kab. Luwu/Palopo.

Bachtiar, Harsya W, dkk., 1988. Masyarakat dan Kabudayaan, Jakarta: Djambatan.

Basri, PdanRukmini, 1979. BiografiPahlawanAndi Jemma datu Luwu, Ujungpandang; Pemda Sulsel.

Dachlan M, Alwi, 1985. Keserasian Hubungan Sosial dalam Masyarakat Majemuk, makalah pada seminar Keserasian Hubungan Sosial dalam Masyarakat Majemuk, 23 Nopember 1985 di Medan.

Direktorat Bina Tata Perkotaan dan Pedesaan Dirjen Cipta karya Dep. Pekerjaan Umum, 1995. Penyiapan Pembangunan Prasarana Kota Palopo, Laporan Intern II Palopo, Ujungpandang: Proyek Penataan Sistem Prasarana Perkotaan dan Kawasan Fungsional Bagian Proyek Penyusunan Rencana Kota dan Kawasan Sulsel.

Ever, Hans Dieter, 1986, Sosiologi Perkotaan, Urbanisasi dan Sengketa Tanah di Indonesia dan Malaysia, Jakarta: LP3ES.

Koentjaraningrat, 1982, Migrasi, Transmigrasi dan Urbanisasi dalam Koentjaraningrat (E.d), Masalah-masalah Pembangunan, BungaRampaiAntropologi Terapan, Jakrata: LP3ES.

Mattata, Sanusi Daeng, 1967, Luwu dalam Revolusi, Makassar: Bhakti baru.

Morris, D.F. Van Braam, 1988, Kerajaan Luwu (Terjemahan H.A.M. Mappasanda; 1993), Ujungpandang: Balai Kajian Sejarah dan Nilai Tradisional Dep. Pendidikan dan Kebudayaan.

P. Badrun, 2002, Segregasi Permukiman di Perkotaan, makalah pada temu peneliti agama se Indonesia di Surabaya.

Paul Johnson, Doyle, 1990, Teori Sosiologi Klasik dan Modern, Jakarta: Gramedia PustakaUtama.

Pemda Tk.II Luwu, 1994. Rencana Umum Tata Ruang Kotif Palopo, Palopo: Pemda Tk. II Luwu.

2001, Potensi dan Day a Tarik Wisata Bumi Sawerigading Luwu, Palopo: Dinas Pariwisata Kab. Luwu.

Puslitbang Kehidupan Beragama Badan Litbang Agama dan Diklat Keagamaan Dep. Agama RI., 2003, Harmoni Jurnal Multikultural dan Multireligius, Jakarta: Puslitbang Kehidupan Beragama Badan Litbang Agama dan Diklat Keagamaan Dep. Agama RI.

, 2003, Seri 11 Konflik Sosial Bernuansa Agama di Indonesia, Jakarta: Puslitbang Kehidupan Beragama Badan Litbang Agama dan Diklat Keagamaan Dep. Agama RI.

Sarita, Pawiloy, 2000. Sejarah Luwu, Makassar: Fakultas Sosial Universitas Negeri Makassar.

Seokanto, Seorjono, 2002, SosiologiSuatu Pengatar, Jakarta: rajawali Pers.

Tim Penanggulangan Patologi Sosial (TP2S) Kabupaten Luwu, 2001, Buku Panduan

Tim Penanggulangan Patologi Sosial Kabupaten Luwu, Palopo, TP2S. 